\title{
VALUES OF ENERGETIC, PROTEIC AND HEPATIC SERUM PROFILES IN NEONATAL FOALS OF THE MARTINA FRANCA DONKEY BREED
}

\author{
Angela Gabriella D’Alessandro ${ }^{1}$, Donato Casamassima², Marisa Palazzo ${ }^{2}$, Felicita Jirillo ${ }^{3}$, \\ Emilio Jirillo ${ }^{4}$, Giovanni Martemucci ${ }^{1}$ \\ ${ }^{I}$ Department PRO.GE.S.A., University of Bari, Italy \\ ${ }^{2}$ Department S.A.V.A., University of Molise, Campobasso, Italy \\ ${ }^{3}$ Department MIDIM, University of Bari, Italy \\ ${ }^{4}$ National Institute of Gastroenterology, Castellana Grotte, Bari, Italy \\ dalex@agr.uniba.it
}

\begin{abstract}
The study aimed to investigate in neonatal donkey foals some serum parameters of the energetic (glucose, cholesterol, triglycerides) and proteic (total proteins, urea, albumine, creatinine) metabolism, and hepatic profile (GOT, GGT, alkaline phosphatase, AP, total bilirubin, GPT, LDH), at 12, 36, 60, 84, 108 hrs and 11 days after birth. The research concerned 10 donkey foals of the Martina Franca breed reared under natural conditions in Southern Italy. All foals, in good health conditions during the study, suckled regularly colostrum/milk from their mothers and were handled carefully. Blood was drawn in the morning from the jugular vein. Serum urea creatinine GPT and AP levels varied $(0.05>\mathrm{P}<0.01)$ with the age of the foals. Within the proteic profile, urea and creatinin levels were higher $(0.05$ $>\mathrm{P}<0.01)$ at 12 hours after birth, as well as AP $(0.05>\mathrm{P}<0.01)$ and GPT $(\mathrm{P}<0.05)$ within the hepatic profile. No differences were found for the energetic serum parameters. Significant correlations $(0.05>\mathrm{P}<0.01)$ were found between all the biochemical metabolities. The present study gives the first reference ranges for serum biochemical concentrations in the authochtonous Martina Franca donkey breed during the neonatal period, constituting basic knowledge for the husbandry system and welfare of foals.
\end{abstract}

Key words: donkey; Martina Franca breed; serum profiles; neonatal period

\section{ВРЕДНОСТИ НА ЕНЕРГЕТСКИ, ПРОТЕИНСКИ И ХЕПАТАЛНИ ПРОФИЛИ НА СЕРУМОТ КАЈ НОВОРОДЕНИТЕ ПРЛИЬА ОД РАСАТА МАРТИНА ФРАНКА}

Целта на студијата беше кај новородените прлиња да се испитаат некои параметри на серумот од енергетскиот (гликоза, холестерол, триглицериди) и протеинскиот (вкупни протеини, уреа, албумини, креатинин) метаболизам, како и хепаталниот профил (GOT, GGT, алкална фосфатаза, АР, вкупен билирубин, GPT, LDH), 12, 36, 60, 84 и 108 часа и 11 дена по раѓањето. Истражувањето опфати 10 прлиња од расата мартина франка, одгледани во природни услови во јужна Италија. Сите прлиња беа во добра здравствена состојба за време на проучувањето, доени беа со колострум од нивните мајки и со нив беше внимателно постапувано. Крвта беше земана наутро од југуларната вена. Нивоата на уреата, креатининот, GPT и AP во серумот варираа $(0,05>\mathrm{P}<0,01)$ со возраста на прлињата. Во рамките на протеинскиот профил нивоата на уреата и креатининот беа повисоки $(0,05>\mathrm{P}<0,01) 12$ часа по раѓањето, како и $\mathrm{AP}(0,05>\mathrm{P}<0,01)$ и GPT (P $<0,05)$ во рамките на хепаталниот профил. Не беа најдени никакви разлики за енергетските параметри на серумот. Значајни корелации $(0,05>\mathrm{P}<0,01)$ беа откриени меѓу сите биохемиски метаболити. Студијава презентира први литературни сознанија за биохемиските концентрации на серумот кај автохтоната раса на магаре мартина франка за време на неонаталниот период, создавајќи основно знаење за системот на одгледување и благосостојбата на прлињата. 


\section{INTRODUCTION}

The new born foals must face significant changes from in utero life concerning respiratory, hematological, endocrine and metabolic aspects, which make their physiological characteristics very different compared to the adults. In the Martina Franca donkey breed (data not published) as well as in horse (Doreau et al., 1989), nursing foals have a very high growth rate, permitting body weight to double between birth and 2 months. Knowledge of these physiological conditions in neonatal foals the form the basis for their management and has important implications in health and welfare. Limited studies have been focused on biochemical profile for donkey breeds and populations (Cubeddu et al., 1991; Jordana et al., 1998; Mori et al., 2003; D’Alessandro et al., 2007) and, to our knowledge no references are available regarding the biochemical serum profile in neonatal foals of the Martina Franca breed. The Martina Franca donkey is an authochtonous breed of Southern Italy, worldwide famous for its tall height, which now is in danger of extinction and is safeguarded.

The aim of this research was to study some parameters of the energetic, proteic and hepatic serum profiles in neonatal foals of the Martina Franca donkey breed.

\section{MATERIAL AND METHODS}

The study was performed on ten foals of the Martina Franca breed from a farm located in Southern Italy at South-Estern Murgia $\left(40^{\circ} 37^{\prime}\right.$ 20 " latitude; $60^{\circ} 17^{\prime}$,44" longitude). Six out of the ten foals were females, four were males. The average weight of foals at birth was $34.7 \pm 4.2 \mathrm{~kg}$ (standard deviation). The group of foals and their mothers were reared under semi-extensive conditions, according to normal breeding practises for the Martina Franca donkey. All foals, in good health conditions during the whole period of study, suckled regularly colostrum - milk from their mothers, and were handled carefully to minimise any possible effects of stress. Blood was drawn in the morning from the foal jugular vein into $10 \mathrm{ml}$ evacuated glass tubes for a serum analysis at 12 , 36, 60, 84, 108 hours and 11 days from birth. Sera samples were analyzed for energetic profile (glucose, cholesterol, triglycerides), proteic profile (total protein, urea, albumine, creatinine), hepatic profile (GOT, GGT, alkaline phosphatase, AP, total bilirubin, GPT, LDH), at 12, 36, 60, 84, 108 hours and 11 days after birth. Serum metabolities, hepatic enzymes, AP, total bilirubin were analyzed in a computerized automated biochemical analyzer (ARCO PC Analyzer - Biotechnica SpA) using commercially available test combinations (Biotecnica Instruments, Diagnostic Line, Rome, Italy).

Statistical analyses were performed using a statistical software program (SPSS, 2003), with statistical differences analyzed by the ANOVA test. Mean differences were compared by the Scheffè's test (SPSS, 2003).

\section{RESULTS AND DISCUSSION}

The values of energetic serum profiles and their changes associated with the age of foals are shown in Table 1. No differences were found in relation to different times from birth. Glycemia ranged from 124.40 (at $12 \mathrm{hrs}$ from birth) to $156.62 \mathrm{mg} / \mathrm{dl}$ (at $11 \mathrm{ds} ; \mathrm{P}>0.05$ ). Also cholesterol showed a tendential higher value at $12 \mathrm{hrs}$ from foaling $(192.00 \mathrm{mg} / \mathrm{dl})$, with a decreasing trend until $108 \mathrm{hrs}(143.30 \mathrm{mg} / \mathrm{dl}$; P > 0.05), and triglycerides ranged from 51.02 (at $11 \mathrm{ds}$ after foaling) to $71.44 \mathrm{mg} / \mathrm{dl}$ ( $84 \mathrm{hrs;} \mathrm{P}>0.05$ ) (Table 1). All these parameters are higher compared to those registered in adult jennies (D'Alessandro et al., 2007). Serum levels of glycemia during neonatal life assume an important role on welfare since foals born with very low stores of glycogen in liver and muscle and blood glucose rapidly drops in the first 2 hours after foaling. Neonatal hypercholesterolemia could be attributable to a low renal functionality (Bauer et al., 1989). Triglycerides trend observed in this study follows that found in the neonatal horse foal (Serrantoni et al., 1997).

Considering the proteic metabolism (Table $2)$, serum urea and creatinine levels varied $(0.05>$ $\mathrm{P}<0.01)$ with the age of the foals, showing the highest values $(0.05>\mathrm{P}<0.01)$ at $12 \mathrm{hrs}$ after birth $(21.64 \mathrm{mg} / \mathrm{dl}$ and $1.78 \mathrm{mg} / \mathrm{dl}$, respectively) and a decreasing trend towards $108 \mathrm{hrs}-11 \mathrm{ds}$ from birth. Total proteins as well as albumin levels were rather constant during the experimental period, ranging from 5.29 to $5.76 \mathrm{~g} / \mathrm{dl}$ and 3.24 to $3.43 \mathrm{~g} / \mathrm{dl}$, respecively $(\mathrm{P}>0.05$; Table 2$)$. Total proteins values in the neonatal phase of foals were lower compared to adults in the donkey 
(D'Alessandro et al., 2007) as well as in the horse (Bauer et al., 1985). In the horse the contemporary decrease of urea has been associated to growth requirements of the foal (Bauer et al., 1984; Piccione et al., 2006).

In relation to the hepatic profile, significant differences were found for AP $(0.05>\mathrm{P}<0.01)$ and GPT $(\mathrm{P}<0.05)$. Results are reported in Table 3. For both these parameters, the highest values corresponded to $12 \mathrm{hrs}$ after birth (AP: 2011.00 $\mathrm{iu} / \mathrm{l}$; GPT: $19.43 \mathrm{IU} / \mathrm{l})$ with a decreasing trend $(0.05>\mathrm{P}<0.01)$ till the $11^{\text {th }}$ day of foals life. Overall, these values are much higher than in adults (donkey: D'Alessandro et al., 2007; horse: Madigan, 2006).

Significant correlations $(0.05>\mathrm{P}<0.01)$ were found between all the biochemical metabolities (Table 4).

Table 1

Energetic profile in neonatal donkey foals

\begin{tabular}{|c|c|c|c|c|c|c|}
\hline \multirow{2}{*}{$\begin{array}{l}\text { Time from } \\
\text { birth }\end{array}$} & \multicolumn{2}{|c|}{ Glycemia (mg/dl) } & \multicolumn{2}{|c|}{ Cholesterol (mg/dl) } & \multicolumn{2}{|c|}{ Triglycerides (mg/dl) } \\
\hline & $x \pm$ S.E. & Range & $x \pm$ S.E. & Range & $x \pm$ S.E. & Range \\
\hline $12 \mathrm{hs}$ & $156.62 \pm 10.40$ & $109.00-200.00$ & $192.00 \pm 30.10$ & $106.00-331.00$ & $62.25 \pm 20.13$ & $23.80-197.00$ \\
\hline 36 hs & $135.49 \pm 8.55$ & $93.40-179.00$ & $174.10 \pm 28.06$ & $93.00-361.00$ & $62.18 \pm 24.80$ & $32.00-101.00$ \\
\hline $60 \mathrm{hs}$ & $126.40 \pm 6.43$ & $92.00-169.00$ & $153.97 \pm 20.59$ & $93.70-307.00$ & $66.98 \pm 8.48$ & $38.50-120.00$ \\
\hline 84 hs & $133.56 \pm 7.72$ & $94.60-164.00$ & $151.32 \pm 19.96$ & $87.20-311.00$ & $71.44 \pm 7.34$ & $32.80-113.00$ \\
\hline $108 \mathrm{hs}$ & $131.00 \pm 4.18$ & $113.00-150.00$ & $143.30 \pm 17.23$ & $93.00-285.00$ & $64.63 \pm 7.08$ & $25.40-100.00$ \\
\hline $11 \mathrm{ds}$ & $124.40 \pm 7.50$ & $104.00-143.00$ & $166.00 \pm 11.95$ & $136.00-201.00$ & $51.02 \pm 19.87$ & $17.20-128.00$ \\
\hline Whole period & $134.69 \pm 3.27$ & $92.00-200.00$ & $161.90 \pm 9.21$ & $87.20-361.00$ & $64.29 \pm 4.47$ & $17.20-197.00$ \\
\hline
\end{tabular}

Table 2

Proteic profile in neonatal donkey foals

\begin{tabular}{|c|c|c|c|c|c|c|c|c|}
\hline \multirow{2}{*}{$\begin{array}{l}\text { Time from } \\
\text { birth }\end{array}$} & \multicolumn{2}{|c|}{ Total Proteins (g/dl) } & \multicolumn{2}{|c|}{ Urea (mg/dl) } & \multicolumn{2}{|c|}{ Albumin (g/dl) } & \multicolumn{2}{|c|}{ Creatinin (mg/dl) } \\
\hline & $x \pm$ S.E. & Range & $x \pm$ S.E. & Range & $x \pm$ S.E. & Range & $x \pm$ S.E. & Range \\
\hline $12 \mathrm{hs}$ & $5.76 \pm 0.21$ & $5.00-6.80$ & $21.64 \pm 3.20^{\mathrm{Aa}}$ & $10.50-32.30$ & $3.43 \pm 0.94$ & $3.10-3.90$ & $1.78 \pm 0.12^{\mathrm{Aa}}$ & $1.40-2.40$ \\
\hline 36 hs & $5.49 \pm 0.18$ & $4.70-6.40$ & $16.88 \pm 2.22$ & $7.80-26.10$ & $3.35 \pm 0.06$ & $3.00-3.60$ & $1.53 \pm 0.08$ & $1.30-2.10$ \\
\hline $60 \mathrm{hs}$ & $5.50 \pm 0.18$ & $4.70-6.90$ & $12.39 \pm 1.10^{b}$ & $6.70-18.60$ & $3.37 \pm 0.04$ & $3.10-3.60$ & $1.41 \pm 0.05^{b}$ & $1.20-1.70$ \\
\hline 84 hs & $5.29 \pm 0.19$ & $4.50-6.50$ & $11.30 \pm 1.14^{\mathrm{B}}$ & $6.40-18.80$ & $3.24 \pm 0.08$ & $2.80-3.50$ & $1.42 \pm 0.05^{b}$ & $1.20-1.60$ \\
\hline $108 \mathrm{hs}$ & $5.36 \pm 0.12$ & $4.60-6.10$ & $11.44 \pm 0.95^{\text {B }}$ & $8.00-18.30$ & $3.40 \pm 0.03$ & $3.20-3.50$ & $1.36 \pm 0.04^{\mathrm{B}}$ & $1.20-1.60$ \\
\hline $11 \mathrm{ds}$ & $5.68 \pm 0.17$ & $5.00-6.00$ & $13.30 \pm 0.89$ & $10.50-15.30$ & $3.26 \pm 0.05$ & $3.10-3.40$ & $1.34 \pm 0.02^{\mathrm{B}}$ & $1.30-1.40$ \\
\hline Whole period & $5.49 \pm 0.07$ & $4.50-6.90$ & $14.14 \pm 0.83$ & $6.40-32.30$ & $3.35 \pm 0.03$ & $2.80-3.90$ & $1.47 \pm 0.03$ & $1.30-1.40$ \\
\hline
\end{tabular}

A, B: $\mathrm{P}<0.01 ; \mathrm{a}, \mathrm{b}: \mathrm{P}<0.05$ 
Table 3

Hepatic profile in neonatal donkey foals (mean \pm S.E.)

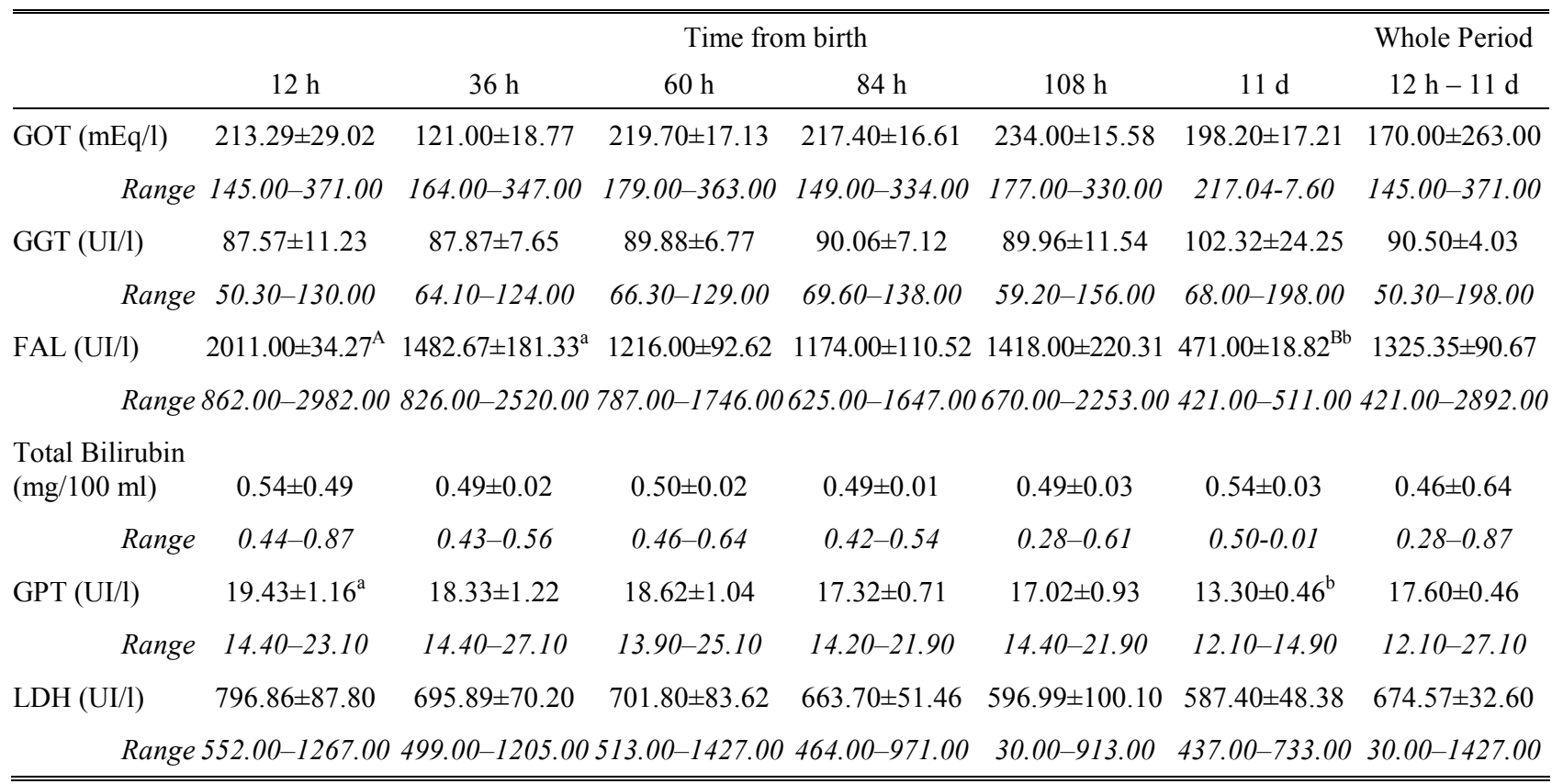

A, B: $\mathrm{P}<0.01 ; \mathrm{a}, \mathrm{b}: \mathrm{P}<0.05$

Table 4

Correlation matrix among the sieric parameters in neonatal donkey foal

\begin{tabular}{|c|c|c|c|c|c|c|c|c|c|c|c|c|c|}
\hline Proteins & $\begin{array}{c}\text { Total } \\
\text { proteins }\end{array}$ & $\begin{array}{l}\text { Albu- } \\
\text { mine }\end{array}$ & Glucose & $\begin{array}{l}\text { Triglyce- } \\
\text { rides }\end{array}$ & Urea $\mathrm{C}$ & Cholesterol & $\begin{array}{l}\text { Creati- } \\
\text { nine }\end{array}$ & LDH & GPT & GOT & GGT & AP & $\begin{array}{c}\text { Total } \\
\text { bilirubin }\end{array}$ \\
\hline Albumin & $0.309^{*}$ & & & & & & & & & & & & \\
\hline Glucose & Ns & Ns & & & & & & & & & & & \\
\hline Triglycerides & Ns & Ns & Ns & & & & & & & & & & \\
\hline Urea & $0.376^{* *}$ & $0.345^{*}$ & Ns & Ns & & & & & & & & & \\
\hline Cholesterol & Ns & Ns & Ns & $-0.314^{*}$ & Ns & & & & & & & & \\
\hline Creatinine & Ns & Ns & $0.314^{*}$ & Ns & $0.533 * *$ & Ns & & & & & & & \\
\hline LDH & Ns & Ns & Ns & $-0.312^{*}$ & Ns & Ns & Ns & & & & & & \\
\hline GPT & Ns & Ns & Ns & Ns & Ns & $0.392^{* *}$ & Ns & $0.417 * *$ & & & & & \\
\hline GOT & Ns & Ns & Ns & Ns & $-0.375^{*}$ & $0.302 *$ & $-0.360^{*}$ & $0.716^{* *}$ & $0.491 * *$ & & & & \\
\hline GGT & Ns & $0.377^{*}$ & Ns & Ns & Ns & $0.514^{* *}$ & Ns & $-0.384 * *$ & Ns & Ns & & & \\
\hline $\mathrm{AP}$ & Ns & Ns & Ns & Ns & $0.373^{*}$ & $0.342 *$ & $0.725^{* *}$ & Ns & Ns & $-0.433 * *$ & Ns & & \\
\hline Total bilirubin & $0.450 * *$ & $0.450 * *$ & Ns & Ns & $0.419 * *$ & Ns & Ns & Ns & Ns & Ns & $0.381 *$ & Ns & Ns \\
\hline
\end{tabular}

**: $\mathrm{P}<0.01 ; *: \mathrm{P}<0.05 ; \mathrm{NS}$ : not significant

\section{CONCLUSIONS}

The present study gives the first reference ranges for serum biochemical concentrations in the authochtonous Martina Franca donkey breed dur- ing the neonatal period, constituting basic knowledge for husbandry system and welfare of foals.

Acknowledgements. Research supported by Interreg Greece-Italy Project (Code I 2101030), Paper N. 21 . 


\section{REFERENCES}

[1] Bauer J. E., Asquith R. L., Kivipelto J. (1989): Serum biochemical indicators of liver function in neonatal foals. Am. J. Vet. Res., 50: 2037-2041.

[2] Bauer J. E., Harvey J. W., Asquith R. L., Mcnulty P. K., Kivipelto J. (1984): Clinical chemistry reference values in foals during the first year of life. Equine Vet. J., 16: 361363.

[3] Bauer J. E., Harvey J. W., Asquith R. L., Mcnulty P. K., Kivipelto J. (1985): Serum protein reference values during the first year of life: Comparison of chemical and electrophoretic methods. Vet. Clin. Pathol., 14:14-22.

[4] Cubeddu G. M., Bini P. P., Floris B., Carangiu V., Bomboi G., Pintori G. (1991): Costanti ematiche dell'asinello bianco dell'Asinara. Boll. Soc. It. Biol. Sper., 67: 577584.

[5] D’Alessandro A. G., Martemucci G., Palazzo M., Simone, N., Colella G. E., Pizzo R, Casamassima D. (2007): Values on serum metabolities in lactating jennies of Martina Franca breed. In: Nutrition and feeding of the broodmare, EAAP Publication No. 120, 2006. Campobasso (Italy), 20-22 June. Wageningen Academic Publishers, 171-174.

[6] Doreau M., Boulot S., Martin Rosset W., Robelin J. (1989): Relationship between nutrient intake, growth and body composition of the nursing foal. Reprod. Nutr. Dévelop., 26 (2): 683-690.

[7] Jordana J., Folch P. Cuenca R. (1998): Clinical biochemical parameters of the endagered Catalonian donkey breed: normal values and the influence of sex, age, and management practises effect. Res. Vet. Sci., 64: 7-10.

[8] Madigan J. (2006). Fondamenti di medicina neonatale (Neonatal medicine step one). 12th Congresso Multisala Società Italiana Veterinari per Equini - SIVE, Bologna, Italy (www.sive.it).

[9] Mori E., Fernandes W. R., Mirandola R. M. S., Kubo G., Ferriera R. R., Oliveira J. V., Gacek F. (2003): Reference values on serum biochemical parameters of Brazilian donkey (Equus asinus) breed. J. Equine Vet. Sci., 23 (8): 358-364.

[10] Piccione G., Costa A., Fazio F., Grasso F., Caola G. (2006): Nitrogenous metabolism in Thoroughbred and Arabian foals from birth to five months of age. Arq. Bras. Med. Vet. Zootec., 58, n. 4, Belo Horizonte ago. 2006.

[11] Serrantoni M., Curadi M. C., Greppi G. F. (1997): Parametri ematochimici nello studio della fase neonatale nel puledro. Proc. 12th Cong. Nazionale ASPA, Pisa, 23-26 giugno, 1997, 333-334.

[12] SPSS, 2003. SPSS for Window, vers. 10.0.7. SPSS Inc., Chicago, IL (USA). 